\title{
Penerapan Helpdesk System dengan Pengujian Blackbox Testing
}

\author{
Implementation Of Helpdesk System With Blackbox Testing \\ Ni Luh Gede Pivin Suwirmayanti*1, I Komang Agus Ady Aryanto ${ }^{2}$ I.G.A. Ngurah \\ Wisrama Putra ${ }^{3}$, Ni Kadek Sukerti ${ }^{4}$, Rosalia Hadi ${ }^{5}$ \\ *1,2,3 Program Studi Sistem Komputer, Fakultas Informatika dan Komputer, Institut Teknologi \& Bisnis \\ STIKOM Bali \\ ${ }^{4,5}$ Program Studi Sistem Informasi, Fakultas Informatika dan Komputer, Institut Teknologi \& Bisnis \\ STIKOM Bali \\ e-mail: *11 pivin@stikom-bali.ac.id, ${ }^{2}$ komang.aryanto@gmail.com, ${ }^{3}$ ngurahwisrama@gmail.com \\ ${ }^{4}$ dektisamuh@gmail.com, ${ }^{5}$ rosa@ stikom-bali.ac.id
}

\begin{abstract}
Abstrak
PT. Rabik Bangun Pertiwi salah satu perusahaan yang bergerak di bidang Jasa Telekomunikasi yaitu di bidang jasa pelayanan Internet yang sudah berkembang sejak tahun 2002. Saat ini, sistem informasi Helpdesk System yang digunakan oleh PT. Rabik Bangun Pertiwi masih dalam proses pengembangan dan masih ada beberapa penyesuaian sehingga diperlukan kembali uji coba untuk memastikan fungsifungsi Helpdesk System dalam hal ini fungsi pencatatan kebutuhan dan permintaan pelanggan, pengaturan penjadwalan dan penugasan staf, serta laporan terstruktur sesuai dengan penanganan yang dilakukan kepada masing-masing pelanggan. Permasalahan yang dihadapi PT. Rabik Bangun Pertiwi ada pada pencatatan informasi keluhan maupun kebutuhan para pelanggan secara manual telah memperlambat kinerja dan efektifitas para karyawan di PT. Rabik Bangun Pertiwi, terutama dalam melakukan update atau analisa dari pencatatan history sebelumnya, sehingga memerlukan waktu yang lebih lama dan mengurangi kualitas respon terhadap keinginan pelanggan. Dengan permasalahan tersebut, PT. Rabik Bangun Pertiwi saat ini menggunakan Helpdesk System yang berfungsi untuk membuat tiket permintaan dari pelanggan maupun calon pelanggan (create ticket), update tiket, pendelegasian tugas (assign ticket), dan penjadwalan petugas (ticket schedule). Dengan menerapkan metode Black Box Testing dalam uji coba fungsi-fungsi dari Helpdesk System. Dari hasil pengujian yang dilakukan hasil yang diperoleh adalah sistem berjalan sesuai dengan tujuan yang diharapkan
\end{abstract}

Kata kunci-helpdesk system, blackbox testing

\begin{abstract}
PT. Rabik Bangun Pertiwi One company engaged in the field of Telecommunications Services is precisely in the field of Internet services which has been developing since 2002. Currently, the Helpdesk Information System used by PT. Rabik Bangun Pertiwi is still in the process of development and there are still some adjustments so that a trial is needed to ensure the functions of the Helpdesk System in this case the functions of recording customer needs and requests, scheduling and assigning staff, and structured reports according to the handling carried out to each - each customer. Problems faced by PT. Rabik Bangun Pertiwi, manually recording complaints and customer needs has slowed down the performance and effectiveness of employees at PT. Rabik Bangun Pertiwi, especially in conducting an update or analysis of the recording of previous history, so that it takes longer and reduces the quality of responses to customer desires. With these problems, PT. Rabik Bangun Pertiwi currently uses a Helpdesk System which functions to create ticket requests from customers and prospective customers (create tickets), ticket updates, assignment assignments, and ticket scheduling. By applying the Black Box Testing method in testing the functions of the Helpdesk System. From the results of tests conducted the results obtained are the system running in accordance with the expected goals
\end{abstract}

Keywords - helpdesk system, blackbox testing

Informasi Artikel:

Submitted: Juni 2020, Accepted: Juni 2020, Published: November 2020

ISSN: 2685-4902 (media online), Website: http://jurnal.umus.ac.id/index.php/intech 


\section{PENDAHULUAN}

PT. Rabik Bangun Pertiwi merupakan salah satu perusahaan yang bergerak di bidang penyedia jasa layanan internet yang berdiri sejak tahun 2002 sampai sekarang. Saat ini PT. Rabik Bangun Pertiwi sudah memiliki sistem yang terkomputerisasi dalam pencatatan ataupun pengaksesan datanya sehingga pengukuran tingkat masalah akan lebih cepat jika ada komplain. Pencatatan suatu informasi pelanggan dapat dibuat secara terstruktur yaitu dari pembuatan data ID pelanggan, pembuatan ID case pelanggan baik itu berupa permintaan informasi, pemesanan baru, laporan komplain, pendelegasian tugas, penanganan komplin beserta history-nya maupun penjadwalan petugas sehingga proses penanganan permintaan pelanggan dapat dilakukan dengan cepat dan efektif. Permintaan pelanggan akan dicatat oleh customer service, kemudian dikumpulkan dalam suatu basis data dan akan diteruskan ke petugas yang ditunjuk untuk menangani permintaan pelanggan. Untuk menangani pencatatan dan penyimpanan data secara terstruktur, PT. Rabik Bangun Pertiwi menggunakan sistem informasi Helpdesk System yang membantu para staf dalam penanganan keluhan maupun penjadwalan dan pendelegasian tugas untuk para staf. Helpdesk merupakan salah satu poin penting dalam organisasi untuk menangani berbagai macam kebutuhan user mengenai pertanyaan, pelayanan, dukungan teknis ataupun keluhan yang dirasakan oleh user[1]. Sistem informasi Helpdesk System yang digunakan berupa web (online), media ini dipilih karena sifatnya yang mendukung mobilitas dan berjalan diberbagai platform sehingga dapat mengatasi perbedaan device dan Sistem Operasi.

Saat ini, sistem informasi Helpdesk System yang digunakan oleh PT. Rabik Bangun Pertiwi masih dalam proses pengembangan dan masih ada beberapa penyesuaian, maka diperlukan kembali uji coba untuk memastikan fungsi-fungsi dalam hal ini fungsi pencatatan kebutuhan dan permintaan pelanggan, fungsi pengaturan penjadwalan dan penugasan staf, serta laporan terstruktur sesuai dengan penanganan yang dilakukan kepada masing-masing pelanggan. Beberapa fungsi tersebut perlu diuji lagi dengan menggunakan metode pengujian Blackbox. Pengujian dengan metode Blackbox dilakukan untuk mengetahui dan memastikan fungsionalitas dari sistem yang telah dibangun tanpa harus menguji desain dan kode program[2]. Blackbox merupakan salah satu pengujian unit terkecil berdasarkan modul yang dibuat dari perancangan detail suatu perangkat lunak [3]. Blackbox testing bukan merupakan pengganti untuk pengujian whitebox, tetapi merupakan sebuah solusi alternative pelengkap untuk menguji hal-hal yang tidak bisa dicakup oleh pengujian whitebox[4].

Pengujian blackbox secara equivalence partitions pernah dilakukan untuk menguji tingkat kesalahan suatu sistem informasi pengelolaan masjid menjadi beberapa kelompok berdasarkan fungsinya (modul) [5]. Selain secara equivalence partitions, pengujian blackbox juga dapat dilakukan secara couse effect relationship testing yang akan menguji kondisi logic dan beberapa aksi yang berhubungan dengannya untuk mengetahui kebenaran fungsi dari aplikasi yang diuji[6]. Hasil yang bagus juga diperlihatkan oleh blackbox testing saat dibandingkan dengan gorilla testing untuk mengetahui reaksi loading time dan delay suatu sistem ketika beberapa user mengakses suatu software secara bersamaan [7]. Kombinasi penerapan helpdesk system dan naïve bayes classifier juga pernah diterapkan pada UPT TIK UNS untuk mengklasifikasikan keluhan yang dirasakan [8].

\section{METODE PENELITIAN}

\section{Alur penelitian}

Metode penelitian yang digunakan dalam penerapan Helpdesk System dengan Pengujian Blackbox Testing (Studi Kasus: PT. Rabik Bangun Pertiwi) adalah metode Waterfall. Waterfall menggambarkan pendekatan yang sistematis dan juga berurutan yakni mulai dari pengumpulan data, analisis sistem, desain sistem, implementasi sistem, dan diakhiri dengan pengujian sistem[9]. Seperti pada penjelasan berikut: 
1. Pengumpulan Data

Pada tahap ini dilakukan suatu proses pengumpulan data dengan tujuan untuk menguraikan proses kerja yang selama ini berjalan. Dari hal tersebut diharapkan mampu mengatasi masalah yang terjadi. Adapun teknik yang digunakan dalam proses pengumpulan data ini adalah observasi, wawancara dan studi literatur.

2. Analisis Sistem

Tahap analisis sistem ini merupakan tahap mengidentifikasi dan mengevaluasi permasalahan, kelemahan, dan hambatan yang terjadi pada proses kerja sebelumnya yang diharapkan dapat diselesaikan dengan sistem ini.

3. Desain Sistem

Tahap pembuatan desain sistem ini dilakukan berdasarkan hasil analisa yang diperoleh. Desain sistem terdiri dari DFD (Data Flow Diagram), ERD (Entity Relationship Diagram), basisdata konseptual, struktur tabel, dan desain antarmuka.

4. Implementasi Sistem

Tahap implementasi sistem merupakan proses merealisasikan hasil analisa dan rancangan sistem yang sudah dibuat menjadi sistem yang bisa dipakai. Helpdesk System di PT. Rabik Bangun Pertiwi hanya bisa diakses dalam jaringan internal perusahaan.

5. Pengujian Sistem

Proses pengujian sistem menggunakan blackbox testing dengan tujuan memastikan bahwa sistem yang sudah dibuat sesuai dengan rancangan dan berjalan dengan baik. Metode pengujian ini berfokus pada input dari pengguna ke sistem dengan mencoba semua fungsi yang terdapat pada sistem tersebut. Hasil output yang dihasilkan oleh sistem tersebut dievaluasi apakah sudah sesuai dengan spesifikasi yang dibutuhkan.

Rangkuman mengenai penerapan alur penelitian yang dilakukan secara waterfall terangkum pada Gambar 1.

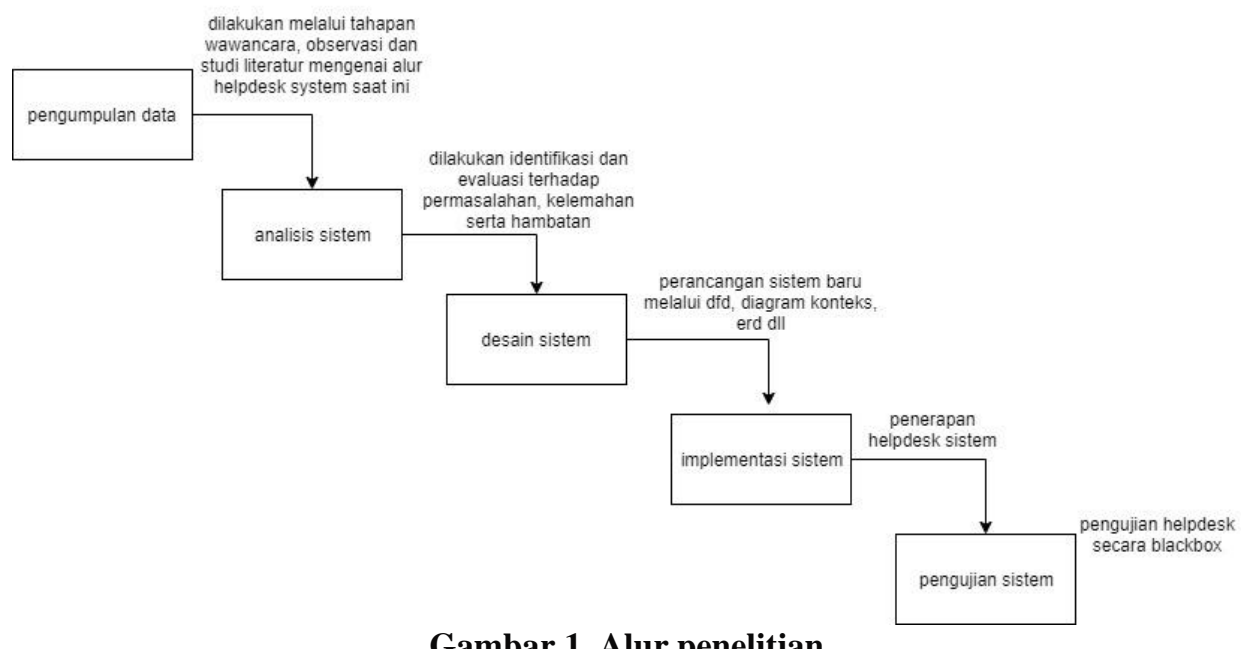

Gambar 1. Alur penelitian

\section{Analisis sistem}

Gambar 1 merupakan rangkuman mengenai sistem low manual Helpdesk yang menggambarkan bagaimana alur atau proses yang terjadi dalam proses Helpdesk dalam hal ini bagian support yang melibatkan Customer, Marketing, Helpdesk, Supervisor dan Network Engginer. Berikut proses permintaan dari pelanggan/calon pelanggan:

1. Jika permintaan pelanggan/calon pelanggan berupa pasang baru selanjutnya hal tersebut diteruskan ke bagian marketing dengan mengisi form survey agar terbuat laporan survey, selanjutnya dari laporan survey tersebut dilakukan proses mengisi data instalasi dan terbuatlah laporan instalasi. 
2. Jika permintaan dari pelanggan/calon pelanggan berupa putus kontrak maka permintaan tersebut diteruskan ke bagian Marketing dengan proses mengisi form putus kontrak dan terbuatlah laporan putus kontrak dan diteruskan ke bagian supervisor yang selanjutnya supervisor meng-inactive account dari pelanggan dan terbuatlah laporan putus kontrak dan proses putus kontrak oleh pelanggan selesai.

3. Jika permintaan oleh pelanggan/calon pelanggan berupa keluhan, maka Helpdesk akan melakukan pengecekan dan terbuatlah laporan pengecekan. Jika hasil pengecekan statusnya Solve maka proses keluhan sudah selesai diproses. Jika hasil pengecekan tidak Solve, maka hasil pengecekan akan di-assign (Assign Ticket) ke Supervisor yang selanjutnya Supervisor akan mengisi form visiting agar terbuat laporan form visiting, dari laporan form visiting ini akan di-assign (assign ticket) ke bagian network engineer, selanjutnya network engineer akan melakukan pengecekan ke lapangan lalu meng-update form visiting. setelah laporan visiting di-update oleh network engineer, maka proses pengecekan on site sudah selesai.

Untuk penjadwalan setiap tiket (schedule ticket) baik itu berupa kunjungan ke lapangan dilakukan oleh Helpdesk sesuai dengan koordinasi dengan pelanggan/calon pelanggan untuk kesepakatan tempat dan jam.

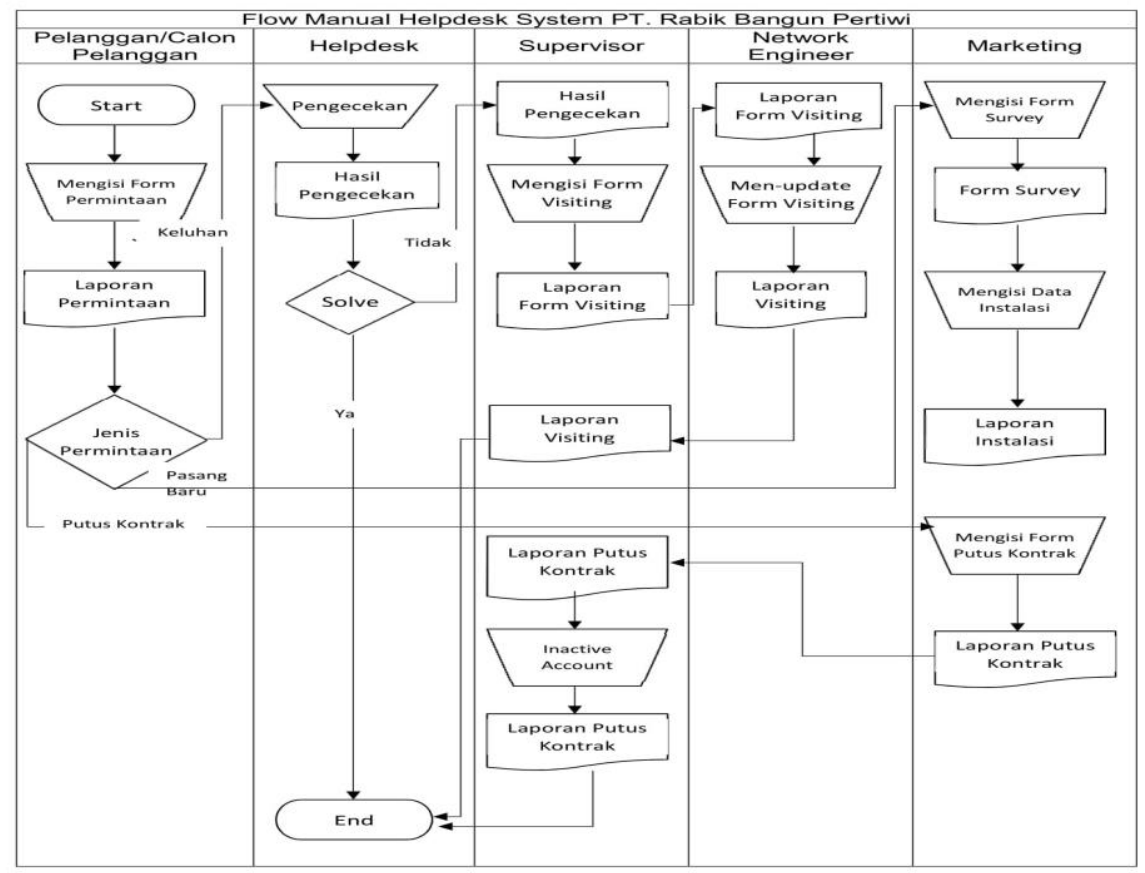

Gambar 1. Flow Manual Helpdesk System

\section{Helpdesk System}

Helpdesk merupakan suatu point of contact dimana seorang user membutuhkan bantuan teknis yang akan menjadikan sarana komunikasi antara user dengan tim pendukung perusahaan[8]. Secara umum keuntungan penggunaan helpdesk sistem adalah dapat memberikan solusi dalam waktu singkat serta dapat meningkatkan efisiensi perusahaan dalam menangani pertanyaan dan keluhan [10].

\section{Blackbox testing}

Blackbox merupakan salah satu pengujian yang lebih difokuskan pada spesifikasi fungsi-fungsi (modul) yang dikembangkan, baik dari sisi struktur data, pengaksesan data dalam database, kesalahan GUI, serta beberapa kesalahan performance yang diberikan [3][11]. Beberapa keuntungan saat penggunaan blackbox testing adalah pengguna tidak perlu memahani bahasa pemrograman yang digunakan dalam sistem, serta pengujian yang dilakukan dilihat dari 
sudut pandang user [12]. Beberapa teknik / pendekatan pada pengujian blackbox diantaranya adalah equivalence class partitioning, boundary value analysis, serta error guessy [13]. Pada penelitian ini akan digunakan metode equivalence class partitioning dengan terlebih dahulu menentukan test case yang akan diuji, test case ini berfungsi untuk menyimpulkan apakah sistem sudah mampu bekerja sesuai dengan yang diharapkan atau tidak[14].

\section{HASIL DAN PEMBAHASAN}

\section{Gambaran umum sistem}

System yang dikembangkan akan menguji performa Helpdesk melalui pengujian blackbox, adapun alur dari pelaksanaan helpdesk system tersebut terangkum pada Gambar 2.

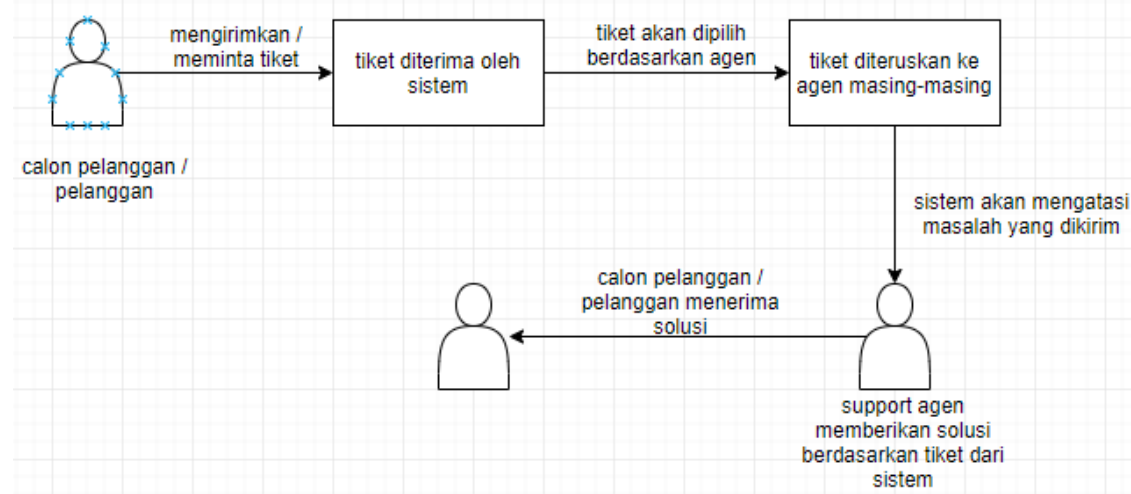

Gambar 2. Helpdesk system yang berjalan

\section{Tampilan halaman helpdesk system}

Halaman Home merupakan halaman utama setelah user melakukan login. Halaman ini berisikan announcement atau berita penting tentang hal-hal yang harus diketahui oleh setiap staff khususnya bagian teknologi. Terdapat juga barisan hari, tanggal dan waktu serta ucapan yang perlu diucapkan oleh setiap user jika menerima panggilan telepon.

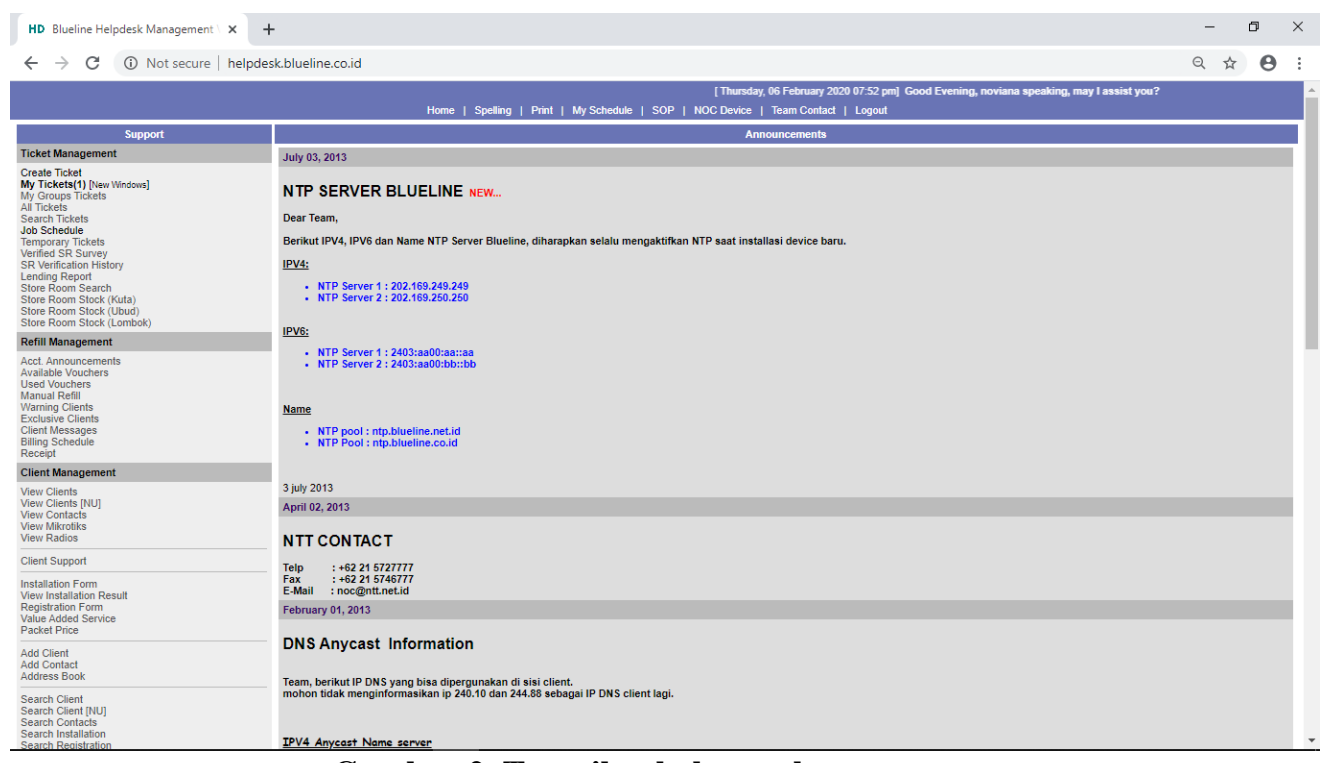

Gambar 2. Tampilan halaman home 


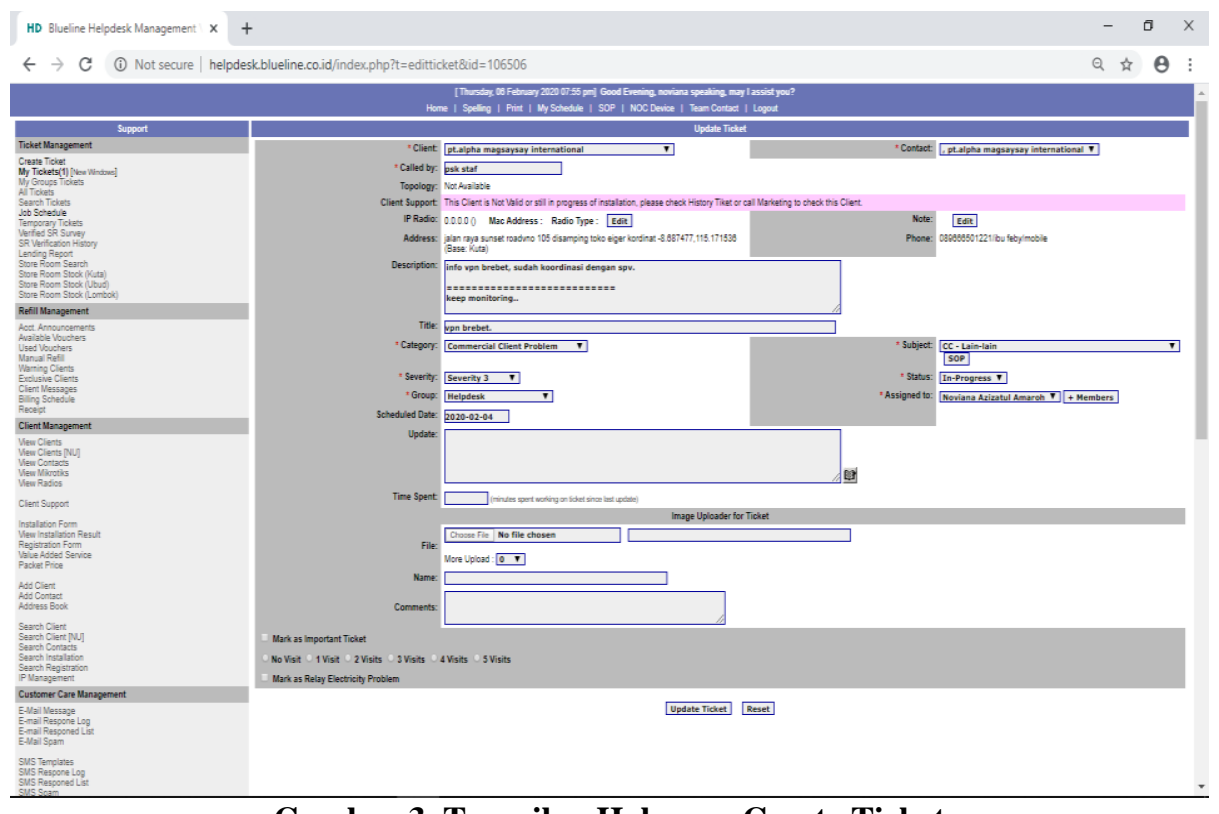

Gambar 3. Tampilan Halaman Create Ticket

Halaman Create Ticket merupakan halaman untuk membuat tiket suatu permintaan, pada halaman ini terdapat menu Client berupa Dropdown List, Called by yaitu nama penelpon, IP Radio merupakan alamat IP dari alat yang di-instal di tempat pelanggan, Description berisikan informasi yang disampaikan pelanggan serta tanggapan yang dilakukan oleh staff (user), Title yang merupakan judul dari tiket tersebut, Category merupakan kategori dari tiket tersebut, dari kategori ini otomatis tiket akan diurutkan prioritasnya (severity) yang berpengaruh terhadap respon/tanggapan setiap staff (user).

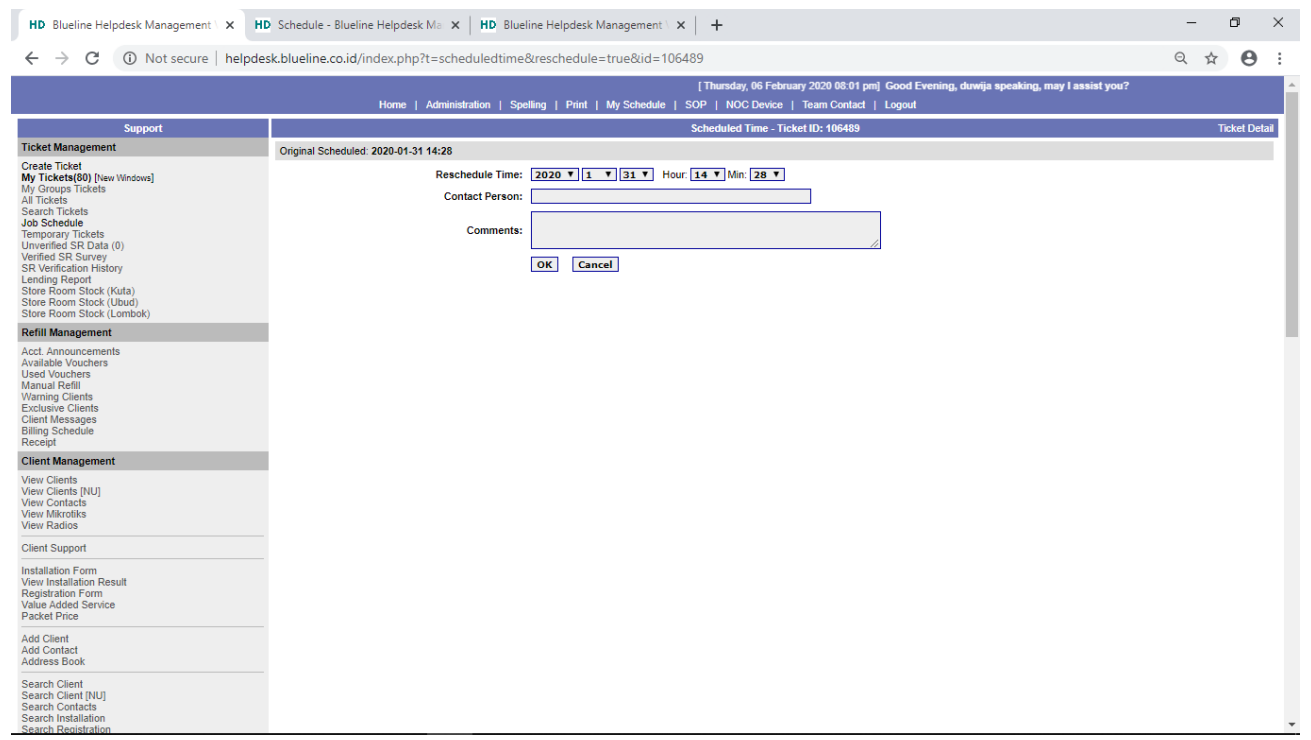

Gambar 4. Tampilan Halaman Schedule Ticket

Halaman Schedule Ticket merupakan halaman yang digunakan untuk mengatur jadwal dari suatu tiket. Biasanya tiket yang dijadwalkan adalah tiket yang perlu dikunjungi atau visiting on-site, tiket inactive account (pelanggan putus kontrak) serta status tiket masih Open, Inprogress dan Pending 


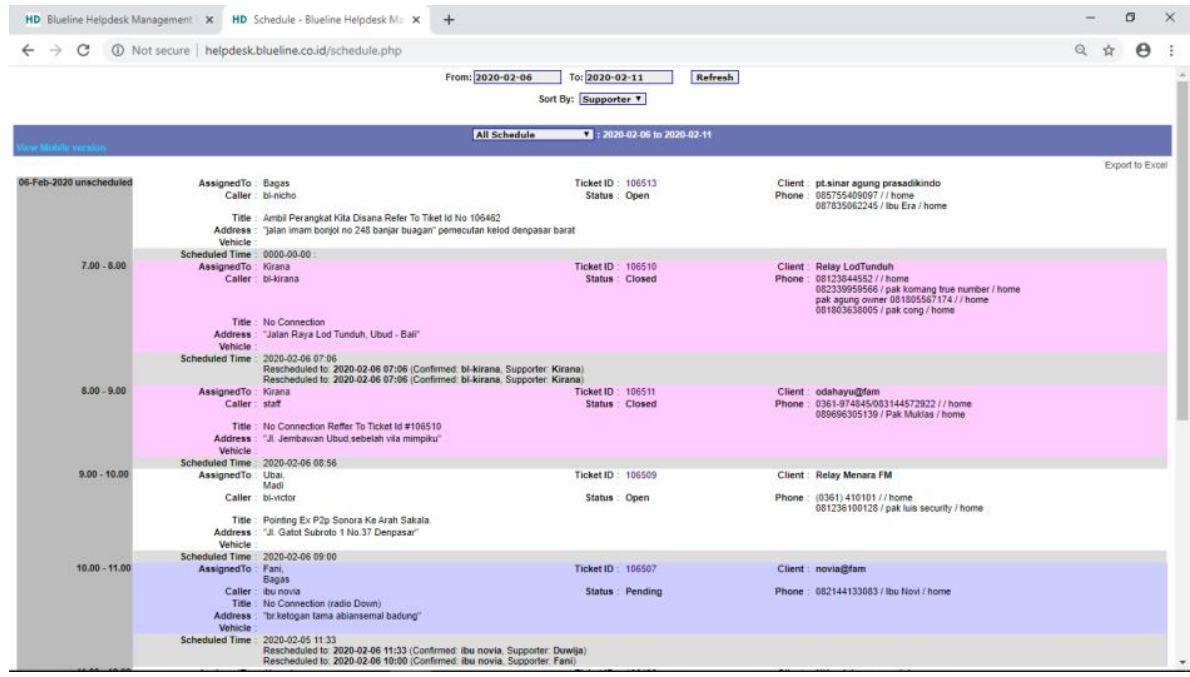

Gambar 5. Tampilan Halaman Job Scheduled Ticket

Halaman Job Scheduled Ticket merupakan halaman yang menampilkan list jadwal tiket yang diurut berdasarkan waktu. Terdapat Field From yaitu user bisa melihat tiket berdasarkan waktu yang diinginkan. Setelah waktu diatur maka akan tampil list tiket berdasarkan waktu yang dipilih.

\section{Pengujian helpdesk system}

Setelah melewati proses implementasi system maka tahap selanjutnya akan dilakukan pengujian Helpdesk System dengan menggunakan metode Blackbox testing. Pengujian dilakukan pada sampel data input untuk menguji fungsionalitas. Berdasarkan form login ada beberapa pengujian yang akan dilakukan. Pada form login terdapat input berupa username dan password, dimana username haruslah nama pegawai tersebut, sedangkan untuk password merupakan merupakan campuran antara huruf kapital maupun angka dengan minimal 8 huruf, tetapi tanpa menggunakan spasi ataupun simbol. Rangkuman mengenai rancangan test case yang akan dilakukan terdapat pada Tabel 1.

Tabel 1. Rancangan test case

\begin{tabular}{llll}
\hline ID pengujian & Jenis pengujian & \multicolumn{1}{c}{ Deskripsi pengujian } & Hasil yang diharapkan \\
\hline TC01 & Form login & $\begin{array}{l}\text { User memasukkan data username } \\
\text { dan password dengan benar lalu } \\
\text { menekan tombol Login. }\end{array}$ & $\begin{array}{l}\text { Proses autentikasi User } \\
\text { berhasil dan diarahkan ke } \\
\text { halaman Home. }\end{array}$ \\
\hline TC02 & Form create ticket & $\begin{array}{l}\text { User memilih User ID yang Data yang dimasukkan oleh } \\
\text { terdaftar dalam database, mengisi } \\
\text { nama Called by, mengisi informasi dalam database dan Ticket } \\
\text { pada field Description, field Title, yang dibuat berhasil diproses. } \\
\text { memilih Category Ticket, Severity }\end{array}$
\end{tabular}
Tickilegory Ticket. Ticket, Subject Ticket, Status Ticket, Group, Assigned to, mengupload data gambar pendukung, mengisi nama gambar pendukung dan mengisi Comments, mencentang pilihan Mark as Important Ticket, mencentang pilihan Visiting dan mencentang Mark as Electricity Problem lalu menekan tombol Create Ticket. 


\begin{tabular}{|c|c|c|c|}
\hline $\mathrm{TC} 03$ & Form update ticket & $\begin{array}{l}\text { User memasukkan data informasi } \\
\text { pada field Update, meng-edit field } \\
\text { Title, Scheduled Date, Assigned } \\
\text { To dan mengklik tombol Update } \\
\text { Ticket. }\end{array}$ & $\begin{array}{l}\text { Tiket ter-update sesuai dengan } \\
\text { data informasi yang } \\
\text { dimasukkan. }\end{array}$ \\
\hline TC04 & Form update ticket & $\begin{array}{l}\text { Tiket tidak bisa di-update dan } \\
\text { muncul pesan untuk mengisi field } \\
\text { Called by. }\end{array}$ & $\begin{array}{l}\text { Tiket tidak berhasil di-update } \\
\text { dan muncul pesan untuk } \\
\text { mengisi field Called by. }\end{array}$ \\
\hline TC05 & Form Schedule Ticket & $\begin{array}{l}\text { User memasukkan gambar berupa } \\
\text { type JPG, JPEG dan PNG lalu } \\
\text { mengklik tombol Choose File. }\end{array}$ & $\begin{array}{l}\text { Nama gambar yang dipilih } \\
\text { tampil dalam field Name dan } \\
\text { gambar yang dipilih ter-upload } \\
\text { ke dalam tiket. }\end{array}$ \\
\hline TC06 & Form Schedule Ticket & $\begin{array}{l}\text { User memilih Combobox Tahun, } \\
\text { Bulan, Tanggal, Hour dan Min, } \\
\text { mengisi field Contact Person dan } \\
\text { mengisi field Comments lalu } \\
\text { mengklik tombol OK. }\end{array}$ & $\begin{array}{l}\text { Data yang dimasukkan User ke } \\
\text { dalam form Reschedule Ticket } \\
\text { ter-update dan diarahkan ke } \\
\text { halaman Detail Ticket. }\end{array}$ \\
\hline
\end{tabular}

Setelah dibuat rencana pengujian, maka langkah selanjutnya yaitu melakukan pengujian berdasarkan rencana pengujian sesuai Tabel 1 . Hasil yang ditampilkan oleh sistem selanjutnya akan dicatat pada kolom hasil pengujian yang kemudian disesuaikan dengan hasil yang diharapkan saat pengujian tersebut dilaksanakan. Ketika hasil pengujian sudah sesuai dengan hasil yang diharapkan maka sang penguji dapat menyimpulkan bahwa sistem berhasil / sukses dan sesuai dengan yang diharapkan, namun jika antara hasil sistem dengan hasil yang diharapkan tidak sesuai maka sang penguji dapat menyimpulkan bahwa sistem tidak berhasil / gagal. Hasil pengujian yang dilakukan terangkum pada Tabel 2.

Tabel 2. Hasil pengujian

\begin{tabular}{|c|c|c|c|c|c|}
\hline $\begin{array}{c}\text { ID } \\
\text { pengujian }\end{array}$ & $\begin{array}{c}\text { Jenis } \\
\text { pengujian }\end{array}$ & Deskripsi pengujian & $\begin{array}{l}\text { Hasil yang } \\
\text { diharapkan }\end{array}$ & $\begin{array}{c}\text { Hasil } \\
\text { pengamatan }\end{array}$ & kesimpulan \\
\hline TC01 & Form login & $\begin{array}{l}\text { User memasukkan } \\
\text { data username dan } \\
\text { password dengan } \\
\text { benar lalu menekan } \\
\text { tombol Login. }\end{array}$ & $\begin{array}{l}\text { Proses autentikasi User } \\
\text { berhasil dan diarahkan } \\
\text { ke halaman Home. }\end{array}$ & $\begin{array}{l}\text { User berhasil } \\
\text { login dan } \\
\text { diarahkan ke } \\
\text { halaman Home. }\end{array}$ & Sesuai \\
\hline $\mathrm{TC} 02$ & $\begin{array}{l}\text { Form } \\
\text { create } \\
\text { ticket }\end{array}$ & $\begin{array}{l}\text { User memilih User } \\
\text { ID yang terdaftar } \\
\text { dalam database, } \\
\text { mengisi nama Called } \\
\text { by, mengisi informasi } \\
\text { pada field } \\
\text { Description, field } \\
\text { Title, memilih } \\
\text { Category Ticket, } \\
\text { Severity Ticket, } \\
\text { Subject Ticket, Status } \\
\text { Ticket, Group, } \\
\text { Assigned to, meng- } \\
\text { upload data gambar } \\
\text { pendukung, mengisi } \\
\text { nama gambar } \\
\text { pendukung dan } \\
\text { mengisi Comments, } \\
\text { mencentang pilihan } \\
\text { Mark as Important } \\
\text { Ticket, mencentang } \\
\text { pilihan Visiting dan }\end{array}$ & $\begin{array}{l}\text { Data yang dimasukkan } \\
\text { oleh User berhasil } \\
\text { disimpan ke } \\
\text { database dan } \\
\text { yang dicket } \\
\text { diproses. }\end{array}$ & $\begin{array}{l}\text { Informasi yang } \\
\text { dimasukkan } \\
\text { berhasil dibuat } \\
\text { dalam bentuk } \\
\text { Ticket. }\end{array}$ & Sesuai \\
\hline
\end{tabular}




\begin{tabular}{|c|c|c|c|c|c|}
\hline & & $\begin{array}{l}\text { mencentang Mark as } \\
\text { Electricity Problem } \\
\text { lalu menekan tombol } \\
\text { Create Ticket. }\end{array}$ & & & \\
\hline TC03 & $\begin{array}{l}\text { Form } \\
\text { update } \\
\text { ticket }\end{array}$ & $\begin{array}{l}\text { User memasukkan } \\
\text { data informasi pada } \\
\text { field Update, meng- } \\
\text { edit field Title, } \\
\text { Scheduled Date, } \\
\text { Assigned To dan } \\
\text { mengklik tombol } \\
\text { Update Ticket. }\end{array}$ & $\begin{array}{l}\text { Tiket ter-update sesuai } \\
\text { dengan data informasi } \\
\text { yang dimasukkan. }\end{array}$ & $\begin{array}{l}\text { Tiket berhasil ter- } \\
\text { updated sesuai } \\
\text { dengan data } \\
\text { informasi yang } \\
\text { diedit dan } \\
\text { diupdated. }\end{array}$ & Sesuai \\
\hline TC04 & $\begin{array}{l}\text { Form } \\
\text { update } \\
\text { ticket }\end{array}$ & $\begin{array}{l}\text { Tiket tidak bisa di- } \\
\text { update dan muncul } \\
\text { pesan untuk mengisi } \\
\text { field Called by. }\end{array}$ & $\begin{array}{l}\text { Tiket tidak berhasil di- } \\
\text { update dan muncul } \\
\text { pesan untuk mengisi } \\
\text { field Called by. }\end{array}$ & $\begin{array}{l}\text { Tiket tidak } \\
\text { berhasil di-update } \\
\text { dan muncul pesan } \\
\text { untuk mengisi } \\
\text { field Called by. }\end{array}$ & Sesuai \\
\hline TC05 & $\begin{array}{l}\text { Form } \\
\text { Schedule } \\
\text { Ticket }\end{array}$ & $\begin{array}{l}\text { User memasukkan } \\
\text { gambar berupa type } \\
\text { JPG, JPEG dan PNG } \\
\text { lalu mengklik tombol } \\
\text { Choose File. }\end{array}$ & $\begin{array}{l}\text { Nama gambar yang } \\
\text { dipilih tampil dalam } \\
\text { field Name dan gambar } \\
\text { yang dipilih ter-upload } \\
\text { ke dalam tiket. }\end{array}$ & $\begin{array}{l}\text { Nama gambar } \\
\text { yang dipilih } \\
\text { berhasil tampil } \\
\text { dalam field Name } \\
\text { dan gambar } \\
\text { berhasil di- } \\
\text { upload. }\end{array}$ & Sesuai \\
\hline TC06 & $\begin{array}{l}\text { Form } \\
\text { Schedule } \\
\text { Ticket }\end{array}$ & $\begin{array}{l}\text { User memilih } \\
\text { Combobox Tahun, } \\
\text { Bulan, Tanggal, Hour } \\
\text { dan Min, mengisi } \\
\text { field Contact Person } \\
\text { dan mengisi field } \\
\text { Comments lalu } \\
\text { mengklik tombol OK. }\end{array}$ & $\begin{array}{l}\text { Data yang dimasukkan } \\
\text { User ke dalam form } \\
\text { Reschedule Ticket ter- } \\
\text { update dan diarahkan } \\
\text { ke halaman Detail } \\
\text { Ticket. }\end{array}$ & $\begin{array}{l}\text { Data yang } \\
\text { dimasukkan User } \\
\text { ke dalam form } \\
\text { Reschedule Ticket } \\
\text { berhasil ter- } \\
\text { update dan } \\
\text { diarahkan ke } \\
\text { halaman Detail } \\
\text { Ticket. }\end{array}$ & Sesuai \\
\hline
\end{tabular}

\section{KESIMPULAN}

Dari pembahasan yang telah sampaikan sebelumnya maka dapat ditarik beberapa kesimpulan bahwa Helpdesk System yang dibangun dengan berbasis web dapat menjembatani adanya perbedaan platform karena saat ini setiap platform sudah mendukung pengaksesan web dengan menggunakan web browser. Web juga saat ini bisa diakses secara mobile dengan perkembangan smart phone yang pesat. Selain itu dengan melakukan pendataan terhadap setiap pelanggan baru maka permintaan informasi maupun keluhan yang dilakukan oleh pelanggan akan selalu dicatat ke dalam sebuah tiket. Tiket ini akan menjadi sumber informasi yang berguna untuk menilai kepuasan client maupun untuk melakukan penanganan jika terjadi permasalahan. Sistem Helpdesk System sudah dilakukan proses pengujian sistem dengan metode Blackbox Testing dengan hasil yang diperoleh sesuai dengan harapan.

\section{DAFTAR PUSTAKA}

[1] E. M. Sipayung, C. Fiarni, and E. Aditya, "Perancangan Sistem Informasi Helpdesk Menggunakan Framework ITIL V3," JNTETI, vol. 6, no. 2, 2017, doi: http://dx.doi.org/10.22146/jnteti.v6i2.308.

[2] W. N. Cholifah, Y. Yulianingsih, and S. M. Sagita, "Pengujian Blackbox Testing Pada 
Aplikasi Action \& Strategi Berbasis Android Dengan Teknologi Phonegap," J. String, vol. 3, no. 2, pp. 206-210, 2018, doi: http://dx.doi.org/10.30998/string.v3i2.3048.

[3] W. Wibisono and F. Baskoro, "Pengujian Perangkat Lunak Dengan Menggunakan Model Behaviour UML," Juti, vol. 1, no. 1, pp. 43-50, 2002, doi: ttp://dx.doi.org/10.12962/j24068535.v1i1.a95.

[4] M. S. Mustaqbal, R. F. Firdaus, and H. Rahmadi, "Pengujian Aplikasi Menggunakan Blackbox Testing Boundary Value Analysis (Studi Kasus: Aplikasi Prediksi Kelulusan SNMPTN)," JITTER (Jurnal Ilm. Teknol. Inf. Ter., vol. I, no. 3, pp. 31-36, 2015, doi: https://doi.org/10.33197/jitter.vol1.iss3.2015.62.

[5] H. Hendri, J. W. Hasiholan Manurung, R. A. Ferian, W. F. Hanaatmoko, and Y. Yulianti, "Pengujian Black Box pada Aplikasi Sistem Informasi Pengelolaan Masjid Menggunakan Teknik Equivalence Partitions," J. Teknol. Sist. Inf. dan Apl., vol. 3, no. 2, p. 107, 2020, doi: 10.32493/jtsi.v3i2.4694.

[6] N. Safitri and R. Pramudita, "Pengujian Black Box Menggunakan Metode Cause Effect Relationship Testing," Inf. Syst. Educ. Prof., vol. 3, no. 1, pp. 101 - 110, 2018.

[7] D. I. Permatasari et al., "Pengujian Aplikasi menggunakan metode Load Testing dengan Apache JMeter pada Sistem Informasi Pertanian," J. Sist. dan Teknol. Inf., vol. 8, no. 1, p. 135, 2020, doi: 10.26418/justin.v8i1.34452.

[8] W. D. Suryono, Saptono, Ristu, and W. Wiranto, "Implementasi Pengembangan Smart Helpdesk di UPT TIK UNS Menggunakan Algoritma Naive Bayes Classifier," Semin. Nas. Apl. Teknol. Inf., pp. 39-43, 2017.

[9] N. A. Ramdhan and D. Wahyudi, "Sistem Informasi Penerimaan Peserta Didik Baru ( PPDB ) Berbasis WEB Di SMP Negri 1 Wanasari Brebes," J. Ilm. Intech Informatioan Technol. J. UMUS, vol. 1, no. 1, pp. 56-65, 2019, doi: https://doi.org/10.46772/intech.v1i01.38.

[10] C. Cassandra, "Pengembangan Model Sistem Informasi Aplikasi Helpdesk Online PT. Mustika Memadata," Comtech, vol. 6, 2AD.

[11] U. N. Sugandi, H. Harliana, and M. Mukidin, "Sistem Pakar Diagnosa Gizi Buruk Balita Dengan Certainty Factor," J. Ilm. Intech Informatioan Technol. J. UMUS, vol. 1, no. 1, pp. 75-85, 2019, doi: https://doi.org/10.46772/intech.v1i02.71.

[12] N. W. Rahadi and C. Vikasari, "Pengujian Software Aplikasi Perawatan Barang Milik Negara Menggunakan Metode Black Box Testing Equivalence Partitions," Infotekmesin, vol. 11, no. 1, pp. 57-61, 2020, doi: 10.35970/infotekmesin.v11i1.124.

[13] T. S. Jaya, "Pengujian Aplikasi dengan Metode Blackbox Testing Boundary Value Analysis (Studi Kasus: Kantor Digital Politeknik Negeri Lampung)," J. Inform. Pengemb. IT, vol. 3, no. 2, pp. 45-46, 2018, doi: 10.30591/jpit.v3i1.647.

[14] M. Syah, A. Kesuma, and P. Gumilang, "Pengujian Black Box pada Aplikasi Sistem Penunjang Keputusan Seleksi Calon Pegawai Negeri Sipil Menggunakan Teknik Equivalence Partitions,” J. Inform. Univ. Pamulang, vol. 4, no. 4, pp. 131-136, 2020. 